\title{
God et al.- World-Making as Collaborative Improvisation: New Metaphors for Open Theists
}

\author{
Mark Steen
}

\subsection{INTRODUCTION}

The Qur'an, Hebrew Bible, and New Testament are full of metaphors. Theologians and philosophers frequently use metaphors to try to understand God, as well as God's relation to humanity and the created universe. ${ }^{1}$ Metaphors, thought experiments, and imagination have played crucial roles in the history of science, and are often used to understand

${ }^{1}$ I'd like to thank Sara Aronowitz, Kelly James Clark, Jeffrey Koperski, and Sam Lebens for helpful feedback on earlier (and unnecessarily corpulent) drafts. Special thanks go to Gabriel Solis, who helped me immensely. Special thanks to Irem Kurtsal for feedback on multiple drafts. Thanks also go to Tyler Denison, Curtis Erhart, Irem Kurtsal, and many more, for the improv and laughs.

M. Steen $(\bowtie)$

Allegheny College, Meadville, PA, USA

(C) The Author(s) 2022

K. J. Clark, J. Koperski (eds.), Abrahamic Reflections on

Randomness and Providence, https://doi.org/10.1007/978-3-030-75797-7_15 
philosophical views ${ }^{2}$ and scientific theories. ${ }^{3}$ Scientific practice is informed by models which are, strictly speaking, fictional and imprecise (e.g., ideal gas laws, 'selfish' genes), and are useful partly because of imprecision. ${ }^{4}$ Metaphors are important. ${ }^{5}$

Metaphors often play an ampliative role, acting as key components in arguments by analogy. If this is legitimate, then thinking metaphorically can not only help us grasp certain theories or phenomenon, but can extend our knowledge. If our metaphors are infelicitous (usually by being unisomorphic), then they can lead us astray. So, while buyer beware, we may not be able to avoid shopping.

We should craft our metaphors to match certain presuppositions, prevent certain key misconceptions, and so forth. But the point of developing metaphors is not just to act as heuristics or illustrations for the unlearned. Metaphors help develop theories at least as much as they can express theories.

Which metaphors should we employ in thinking about God, and His relation to us and our cosmos? I have witnessed the unsurprising fact that most of the metaphors about God and His relation to the world support, and are supported by, Classical Theism, as opposed to more unorthodox theories like Open Theism (OT). But I am an Open Theist and metaphorlover, and think Open Theists should be invited to the Metaphor Party. So I decided to explore some novel metaphors after canvassing those for Classical Theism.

This paper is not a direct argument for Open Theism (OT). I rather hope to show how improvisational metaphors illustrate the OT picture, whereas traditional metaphors are unsuitable. I also will show how

\footnotetext{
${ }^{2}$ One example is the Crossword Puzzle analogy of Susan Haack for understanding 'Foundherentism.' See Haack 1993.

${ }^{3}$ Think of how Einstein imagined chasing photons or riding inside space ships in order to develop Relativity Theory, or how Galileo trounced Aristotle's theory of gravitational acceleration being a function of mass (see Gendler, Thought Experiment, and Frigg "Models and Fiction"). Also, all of us who took high school physics remember Newtonian physics being illustrated by non-existent frictionless Euclidean planes, perfect spheres, and General Relativity by thinking of a planet bending space like a bowling ball on a blanket. There is also 'Hilbert's Hotel' with regard to mathematics, and so on.

${ }^{4} \mathrm{~A}$ model must be simpler than what is a model of, given human limitations and our need for practicality. (C.f. Frigg 2010).

${ }^{5}$ In ways both bad and good. Think of the result of depicting 'the other' as vermin, rats, viruses, contagion, and so on.
} 
understanding them makes OT more plausible and coherent with traditional models of God's authority. Plus, they're fun to think about.

\subsection{Classical Theism and Its Metaphors}

Open Theism holds that God is (at least partly) temporal and does not know which future contingent events will occur. This includes free choices as well as undetermined natural events. This view is the combination of theism with the doctrine that the future is 'open' or not settled-either by God or by the laws of nature.

Classical Theism holds that God is outside of time (in 'eternity'), and knows everything which will occur (even future contingents). The following chart will give a somewhat caricatured flavor of the differences between these views.

\begin{tabular}{|c|c|c|}
\hline Question & Classical Theist & Open Theist \\
\hline $\begin{array}{l}\text { Does God know } \\
\text { everything that will } \\
\text { happen? }\end{array}$ & Yes & No \\
\hline Is God temporal? & No & Yes (in some sense) \\
\hline Does God change? & No & Yes (except in His character) \\
\hline How sovereign is God? & Meticulously so & $\begin{array}{l}\text { Allows free will and } \\
\text { randomness }\end{array}$ \\
\hline $\begin{array}{l}\text { Will all of God's } \\
\text { purposes be fulfilled? }\end{array}$ & $\begin{array}{l}\text { Exactly as planned (according } \\
\text { to the most precise plan) }\end{array}$ & $\begin{array}{l}\text { As planned (but not according } \\
\text { to the most precise plan) }\end{array}$ \\
\hline Does God take risks? & $\begin{array}{l}\text { No (no contingency plans } \\
\text { needed) }\end{array}$ & Yes (with contingency plans) \\
\hline
\end{tabular}

\subsubsection{The Bird's-Eye View}

Aquinas developed the theological metaphor of the Bird's-Eye View. ${ }^{6}$ While some travelers on a twisty mountain road can't see around the corner ahead, a bird in flight can, with its privileged view from above. If we make the bird analogous to God, the road to time, and us to the travelers, then the result is somewhat obvious. God sees all of time, including the future, laid out at once, while we are bound to a road segment at a time.

\footnotetext{
${ }^{6}$ Summa Theologica, part I., Article 13.
} 
Something like the road analogy, the notion of the 'Block Universe,' is employed in non-theological contexts. We are asked to view the Universe as shaped like a stick of butter, with $2 \mathrm{D}$ slices of the butter representing actual 3-dimensional "time-slices" of a world, with the length of the stick representing the fourth dimension, time. ${ }^{7}$ Space and time aren't distinguished on this view - there is only space-time. The Block Universe view (also called "Eternalism") is often held to be supported by Relativity Theory, not theology, but science-minded folk of a certain theological bent can find in this yet more support. On this kind of view the present is in no way privileged, all times are equally real, and time does not really 'flow.'

This type of metaphor is ubiquitous, as it is simple, powerful, and visual, and the idea of God 'above' looking 'down' at all of space-time laid out in an instant gives an idea of God in eternity sufficient for most folk purposes.

According to this picture God does not act in time, nor does He need to. One act, sub specie aeternitatis, is sufficient to both create the world and commit all acts of particular providence, since He foreknows and responds accordingly beforehand. ${ }^{8}$

\subsubsection{God as Instantaneous Author}

A common metaphor for how God stands to the world is as how an author stands to their novel. 'Author,' etymologically overlaps 'authority,' and it has long been held that the author is the best authority on their work. Not merely in the interpretation of it, but, tautologously, in the writing of it. Authors just lay down, by fiat, what happens in their stories. And God speaks it, and it is. As Susan Lanser remarks, "It is not accidental that we use the term author to refer to God or that the root of the word 'authority' links it to the notion of the creator or promoter" $(1981,84)$.

\footnotetext{
${ }^{7}$ See, for example, Sider, Four Dimensionalism, or Heller 1990.

${ }^{8}$ While sitting in a seminar of Eleonore Stump's, I saw her use a pretty ingenious metaphor. Imagine a long table covered with a long tablecloth and place settings. By tugging on one end one can affect every object on the table at once, hence having causal effects where one is not present. Metaphorically, making times analogous to places on the table, God can 'tug' the world just once and affect every subsequent time, without being 'at' those times.
} 
Sam Lebens, in "God and his imaginary friends: a Hassidic metaphysics," entertains the idea that the world is God's lucid dream, or a story He's imagining. ${ }^{9}$

I call it 'Hassidic idealism,' since the idea isn't that the world doesn't exist. ...The idea is that for anything other than God to be real is for it to exist in the story that God is spinning in his mind. This is a radical form of idealism. (2017, 163, italics his)

It's a gripping and rich analogy to compare world creation to book creation. Books, whether fictional or not, seem to describe some of the world. ${ }^{10}$ Anna Karenina may not exist, but she could have, and those fictional events could have occurred.

Sometimes a novelist is called a 'world-maker', and we talk about "the world of Dickens" and such, and it has become common for fantasy and sci-fi authors to construct 'magic systems' or extraterrestrial cultures.

While non-fictional works represent the actual world, what do fictional works represent? Many have thought they represent 'possible worlds,' or, ways the world could be. What are possible worlds? According to Leibniz they are compossible sets of possibilia (and possibilia are 'complete concepts' in the mind of God), but many ${ }^{11}$ have treated "possible worlds" more metaphorically, as 'World-Books,' that is, maximally specific and exhaustive sets of propositions. The idea that 'possible worlds' are like Fictional World Books, whereas the Actual World's Book is the only one representing a real thing, is an extremely popular one. ${ }^{12}$ There are many different views in this neighborhood, but the shared idea is that worlds are identical with, or represented by, consistent sets of sentences or

\footnotetext{
${ }^{9}$ In this he is inspired by Hefter's (2013) interpretation of Rabbi Leiner (1995). Lucid dreams occur when one is aware that one is dreaming, and can consequently direct it to some extent.

${ }^{10}$ An alien archaeologist, far in the future, finding a copy of Napoleon: A Life (by Andrew Roberts), could be forgiven from thinking this is fiction, or that Dangerous Liaisons (an epistolary novel by Pierre Choderlos de Laclos) is a collection of actual letters.

${ }^{11}$ Mostly semanticists or modal logicians, who often regard 'possible worlds' in a merely functional or heuristic manner.

${ }^{12}$ You can find over twelve theories comparing possible worlds to books (or linguistic entities). See Divers 2002, 178-179 for details.
} 
propositions. John Divers calls such proponents "Book Realists." 13 These possible worlds are not like those of speculative cosmology and physics. There is no spatiotemporal path from our world to these, and they are fundamentally different kinds of entities. ${ }^{14}$

For the Classical Theist Book Realist, God authors these books, outside of time. 'The book' which represents the world is authored instantaneously. God knows any way a world could be, since He knows all the possible objects and properties, aggregates every possible combination of them, and picks one world to 'actualize,' where every last detail is settled. Every possible world-book, including what will become the actual world, is already 'written.'

\subsubsection{God: The Lone World-Artist}

A ubiquitous metaphor is that God stands the world as an artist to their work of art. But which kind of medium is the world best viewed as? Like a painting? A song? Maybe a film.

Regardless of the metaphor, the Classical Theist adheres to two main points. First, the World Artwork is not a collaborative project, and the only artist is God Himself. Second, the artwork is birthed complete and entire. God is in eternity; He does not fiddle about in time. His creations may exist in time, but their past, present, and future are all equally known to Him. His difference-making contribution to the world is completed upon creation.

\subsubsection{Problems with the Metaphors}

For the Open Theist these metaphors just won't do: they don't reflect the world as she sees it, God as she sees Him, nor do they capture the relations between Him, the world, and us.

For example, on the Bird's-Eye View metaphor, the 'journey' is all laid out, and our future is just another part of the Block Universe, just as real as the present. A completed book is one where, while the protagonist is deciding on one page, the decision is already settled on a later

\footnotetext{
${ }^{13}$ Divers, Possible Worlds.

${ }^{14}$ At least, according to most. Some people are 'modal realists' who think that all possible worlds exist in the same way, and ours is not privileged in any way. See Lewis, On the Plurality of Worlds.
} 
page-hence not free. Completed books, films, audio files-if made instantaneously - could not have evolved differently. By collapsing the distinction between completed films and filming, they end up with films whose constituents could not have made the film any different than it in fact is.

These concerns are used, not to argue against Classical Theism, but to help construct desiderata for metaphors amenable to the Open Theist. I believe the OT'ist should consider the following five desiderata which are in bold.

Metaphors for the Open Theist should shed light on how petitionary prayer can change God's mind. That is, they should support a model where something occurs which would not have occurred had the petitioner not prayed, where it was open before the prayer whether it would be prayed or not. So, this leads to the open future desideratum, which is also necessary in order to allow Libertarian free will in general.

The metaphors should also shed light on how providence works, both in general and in particular instances, whether miraculous or not. The metaphors should show both how God takes risks, while allowing us to have confidence in Him and His plans.

A corollary to some of the aforementioned for Open Theists who, like myself, accept quantum randomness is that randomness must be compatible with, or illustrated by, the metaphors.

\subsection{Metaphors FOr Open Theists}

I will briefly cover two discussed metaphors amenable to OT, but I'm mainly interested in the two I will propose, which share the feature of improvisation. The main point of this essay is that improvisational metaphors more accurately capture the spirit of OT, which sees God and free agents as unequal collaborators in making the world be the one that it is and will become.

\subsubsection{The Shrinking Tree}

Storrs McCall (1994) makes use of a branching model of time in order to lay out a hybrid 3D/4D view which invokes the metaphor of a 'universe tree.' The rough idea is that we can think of the past as like the trunk of a 
tree, and all the possible futures are like branches. ${ }^{15}$ The present is the point of the trunk where the bottom-most branches join the trunk, and we can envision it like a saw blade. As it moves up the trunk, it lops off unactualized branches. Suppose that event el can be followed by (mutually exclusive) e 2 or e 3 . If e 2 occurs, e 3 is simultaneously 'lopped off' by the saw of the present. It is no longer possible. As time moves on, the future possibilities get lopped off, and, while the 'tree' shrinks, the 'trunk' of the past expands.

Before the 'saw of the present' chops off the other branches, there is nothing ontologically privileged about the future which will come to be, since it was not determined that it would come to be. If it was determined that a branch would not occur, then it wouldn't be a 'choppable' branch in the first place.

I find this model and metaphor extremely helpful and plausible, since it gives a surrogate for God's knowledge of the future in Classical Theism, namely, God's knowledge of all possible futures.

\subsubsection{More Dynamic Metaphors: 'Books-in-Progress' and the 'Growing Block'}

Static Classical Theists don't necessarily have a monopoly on the novel metaphor. A Dynamic Open Theist could employ it in a different way. They may have a different view of what novels are.

Static theorists see novels as sequentially ordered sets of propositions. But one could, and maybe should, see it differently. The writing of a book is an event, and the reading of a book is an event. Words, by themselves, just sit there, just like individual film cells on a motion picture reel. In order to work, the novel needs movement and perception just as much as the film does (and, arguably, more active imaginative involvement). Novels are a means to an end in a certain medium, the end of having certain experiences. ${ }^{16}$ The squiggles on the novel's pages are a means. Toward what end? The generating of certain imaginings and representations in the reader. One could view the writing of a book more dynamically. That is how authors experience the writing and readers the reading. Texts, when used as directed, move. Read, turn page, repeat.

\footnotetext{
${ }^{15}$ Which themselves have branches, ad infinitum, unless there's a final moment.

${ }^{16}$ And thoughts, if you think the term 'experience' doesn't capture propositional content.
} 
So, book metaphors need not be the sole province of Static Classical Theorists. God stands to the world as an author does to a book she is writing. Half-finished novels are no less real than finished ones. ${ }^{17}$ So, just like half-finished houses being built are not half-real completed houses, but rather real half-built houses, so are half-finished novels not half-real completed novels, but rather real half-finished novels, or, we could say, books-in-progress. ${ }^{18}$

And perhaps we are characters in the world-novel being written which could 'possess' God in the way that characters possess authors. ${ }^{19}$

One further metaphor which can act as an adjunct to the book-inprogress metaphor is a view of the nature of time-the Growing Block.

C.D. Broad thought of space-time in a way akin to Eternalism, but with a crucial caveat. The block is growing - growing into the future. "Fresh slices of existence" keep getting added to the block, which accounts for the flow of time.$^{20}$ For Broad, the past and present are real, but the future is not. It does not yet exist. Combined with a denial of determinism, which slice will be added next is not settled.

The theistic Growing Blocker can see God as either adding each slice or setting up the block as grow independently, or some blended view. While a Growing Block theorist has flexibility with regard to dynamism and determinism, their view will invariably be more dynamic than any Eternalist view.

\subsubsection{God as Collaborative Improvisational Director-Participant}

According to the most apt metaphors I find for God in relation to the world, He is an improvisatory director and co-performer. I will examine in particular the metaphors of God as a jazz ensemble head, and as an improvisational play director-participant.

\footnotetext{
${ }^{17}$ Relatedly, how one sections a long book or series is somewhat arbitrary, and so whether one is finished with a book or in fact working on a sequel is somewhat arbitrary too.

${ }^{18}$ C.f. Szabo-Gendler 2008.

${ }^{19}$ In terms of surprising the author. I'm not supposing that we are pushing God around. There is a well-known phenomenon that fiction authors deal with, called 'character possession,' where it seems that the characters are telling the author what they will do rather than the other way around. Just to be clear, I don't think this is literal possession.

${ }^{20}$ Broad 1923, 66. Note that the issue of determinism is orthogonal to the question of the growing block.
} 
Since it is a component of both metaphors, we can begin by laying out some of the elements of improvisation. ${ }^{21}$

\section{Spontaneity}

Spontaneity in performance is the soul of improv, even if an artifact is a goal. Something is improvised, in part, by being made up 'on the fly,' or not prepared beforehand. We can see it in dance, music, some painting (e.g., Pollock's flinging of paint), film, theater, 'automatic writing,' William Burrough's découpé, 22 and so forth.

Some works are completely improvised, some partially improvised, and the improvised elements can be structured and prepared to different degrees.

\section{Structured}

Ad-lib does not mean ad hoc. Improvisation is not purely random behavior or gobbledygook. In improv theater and jazz, the goal is a structured or coherent performance. There may, and perhaps must, be elements of randomness, but the whole should not seem completely random.

\section{Collaborative Yes-And'ing}

We are looking at collaborative improvisational forms. Improv theater and jazz bands work together to make a single work. One is a member of a team, and team goals trump personal ones. If someone in improv tries to stand out or works against their colleagues' contribution, the work usually suffers. Scenes only work if the players focus on doing what's right for the scene and characters, and build on, rather than deny, their colleagues' introduced content.

\section{Playfulness}

Arguably, improvisation is playful. It is participated in for joy and recreation, even if it has a serious purpose or application. One of the main draws for both artist and audience is that it is fun, even though (or partly because) it is difficult.

\footnotetext{
${ }^{21}$ See Zaunbrecher 2011 for more detail.

${ }^{22}$ Burroughs 'wrote' some pieces by cutting out words and randomly selecting them, while making some corrections for grammar and coherence.
} 
Aesthetics of Ephemerality in Live Performance

Improvised art forms have aesthetic novelty. The most 'pure' improv and jazz are made to be performed live. In improv, this has to do with audience participation. Usually the direction an improv game or play takes will start with audience suggestions. Audience members are often asked to participate, sometimes on stage. Audiences usually cut a lot of slack to the performance that they wouldn't with a written play. Improv is selfconsciously so, and that's part of what makes it the practice it is. In both improv and jazz the mutual interaction between performers and audience often makes a difference to the performance.

The ontology of an improv play is arguably different from a written one, and the same goes for an improvised jazz performance versus a recording, or a fully composed piece. ${ }^{23}$ This has to do with entrenched Western ideas of what works of art are, as well as the distinction between composition and performance. With Western classical music, performer and composer are usually distinct, and the different performances are seen as different instances (or, 'tokens') of the same work (or 'type').

But the distinction between type and token breaks down with improv. In most cases, the performer and composer are one and the same, and the composition and the performance (to some extent) are one and the same. My friends Curtis Erhart and Tyler Denison, members of the improv troupe Ephemerata, begin every play by saying, melodramatically, "this play has never been performed before - and will never be performed again."

While there still are kinds of improv, both 'long-form' play structures (La Ronde, the Harold) and 'short-form' games (Word-at-a-time, Film Dub, etc.), performances in these structures are not different instances of the same work of art. The games are merely rules employed to shape spontaneous composition of plays.

With the most avante-y of Avant-Garde Jazz, every performance and composition are the same. With mainstream jazz, there are indeed different versions of the same piece, but some of the composition happens on the fly, so they are not instantiating a preexisting completed work.

Domenico Pietropaolo, while abstracting away from all the differences in the different schools of commedia dell'arte (the precursor of modern improv), analyzes commedia dell'arte as a "stochastic composition process" (Pietropaolo 1989).

${ }^{23}$ C.f. Solis, 316. 
We can look at the various jazz soloing conventions and the formats of long- and short-form improv as stochastic composition processes. These are rules for making pieces and plays, which rely on randomness as a contributory agent. Randomness-it's not a bug, it's a feature!

\subsubsection{Example 1: Jazz Band Leader}

I am not the first to make a metaphorical connection between jazz and OT. Darryl Wooldridge on Sanders:

Open Theism ... proposes that God's give-and-receive relationship with humans requires that they have freewill and that God's actions are contingent upon human unknown actions. It is freewill that may change God's flexible strategies making macro predestination viable but micro predestination contingent, a bit like improvisational jazz solos within an overriding melody (Sanders 2007, 245). In other words, there is an unstructured or unknown polyphonic, improvisational element to human existence for which God accounts and responds, in real time, in harmonic kind. ${ }^{24}$

I am going to assume some familiarity with jazz ${ }^{25}$ and will mostly refer to mainstream jazz of the 1940s and 1950s (especially 'Cool Jazz'). These works, like all jazz, have some amount of pre-arranged structure. ${ }^{26} \mathrm{~A}$ familiar structure is a standard bop format, which is as follows: "there is an introduction, followed by the head, a series of solos and finally a closing recapitulation of the head" (Solis, 317). The 'head' is the main theme or melody of a song, and, very often, the work has a 32-bar AABA structure. ${ }^{27}$

The head remains recognizable in the piece's different versions, while improvisation provides for the difference. Every performance of an improvised jazz piece is different.

Improvisation is so central to jazz that 'covers,' or replication, is impossible. The band Mostly Other People Do the Killing (MOPDTK) did a painstaking, note-for-note reproduction of Miles Davis' album Kind of Blue. How can an intrinsic duplicate of a jazz performance not be the same

\footnotetext{
${ }^{24}$ Wooldridge 2014, 65.

${ }^{25}$ For those unfamiliar with the genre, here are some paradigmatic exemplars of the subgenres discussed in this paper: John Coltrane, "Alabama": https://tinyurl.com/y343ef6s, Miles Davis, "So What?”: https://tinyurl.com/d3mack3, Thelonious Monk, "Don't Blame Me": https://tinyurl.com/ls2xlbh

${ }^{26}$ Some Avant-Garde works excluded.

${ }^{27}$ Solis, 317
} 
jazz composition? Because, as (band leader) Elliott puts "it, 'the defining characteristic of jazz is improvisation,' and that's by definition precluded from this project." ${ }^{28}$ Exact intentional replication is impossible since spontaneous creation is essential to the piece.

In jazz sheet music, there is often notation indicating when improvised solos should occur. ${ }^{29}$ So, if one is not improvising, one is not playing the piece. MOPDTK weren't improvising "So What?," so they weren't playing it. Copying is not improvising. They weren't doing what Davis and crew were. Whether or not one is playing jazz is not intrinsic to the musical sounds, it depends on the intentions and preparations, or lack thereof, of the musicians.

Most small group jazz collaboration requires continuous simultaneous co-adjustment. They need to be playing with each other, not merely beside each other, and need to be creating something new as a group. Ingrid Monson colorfully describes how this fails in the following, even when the result sounds decent:

I hate hearing them bands where like ... one cat's playing some shit that he practiced. Another cat's playing some shit that he practiced. Everybody's playing some stuff that they practiced. ... On a certain level there's like a feeling, "Well, I like playing with you," but ... what does that mean? ... You know, we didn't play shit together. We didn't do nothing together. I played my stuff, you played your stuff, we didn't screw up the time. ${ }^{30}$

It would, however, be a misconception to think that jazz solo work comes ex nibilo out of the head of the composer, in the moment. David Sterritt shows (as should be obvious) how jazz improvisation is based on hours of practicing and learning the various 'tricks' for improvising performances. "The allegedly inherent traits of improvisation-authenticity, spontaneity, individuality," which can give the art, and the artist, an air of mystique, or an aura of cool, "are often exaggerated or misrepresented by its advocates," 31 Arguably, many improvised solos are pre-composed in part. As Thomas Owens states, all spontaneous performances "were

\footnotetext{
${ }^{28}$ See https://tinyurl.com/ybf875yh

${ }^{29} \mathrm{Or}$, at least, there is always an assumed convention that solos should occur during the piece.

${ }^{30}$ Monson 1995, 84. My source is Solis, 333.

${ }^{31}$ Sterritt, 166.
} 
actually precomposed in part ... no one can create fluent, coherent melodies in real time without having a well-rehearsed bag of melodic tricks ready." 32 And Sterritt states that "the typical improviser's mind ... is 'stuffed with a congeries of motifs, instrumental sounds ... scales, chords, modes, and the rest." 33

This is not to denigrate jazz improvisation. While genuinely improvised, we must understand that the performance comes from disciplined preparation, shaping novel sounds from familiar material. It's the same with improv. Improvisers practice accents, character types, games, transitions, and so on.

If God interacts with us like a jazz band leader, perhaps we should look at an example.

John Zorn, while not a paradigm jazz band leader, provides a good example. A saxophonist, he plays and composes in many different genres. In the piece I will discuss (at https://tinyurl.com/pa6ue $3 \mathrm{~h}^{34}$ ), Zorn is solely directing. The piece's head is a simple guitar riff, ${ }^{35}$ a few bars long, together with a keyboard chord progression. It begins by the guitarist, Marc Ribot, improvising with notes echoing the main riff, and Zorn points to his head when he wants Ribot to start playing the head, and, as you can see, he directs changes in tempo, volume, and points in certain ways when he wants an individual to solo or cease soloing. The keyboard chords act as an 'anchor' to give continuity and coherence to the piece, and when it's time for the keyboardist's solo, the head is taken up by Ribot to keep things anchored while the keyboardist wanders. You'll notice that at 3:29 Zorn pokes Ribot's leg to get his attention and points to his head to indicate the solo should end and he should get back to the head of the song. Ribot doesn't immediately go back to the head, but improvises a sensible way back, Zorn trusting Ribot to do this. You can see the constant microcommunications not just between the leader and band members, but directly between band members, and indirectly between members via the leader as a focal point.

This hopefully suffices to get the idea across how improvisational music is 'dialogical,' developing communicatively and communally among the

\footnotetext{
${ }^{32}$ Owens, 30. My source is Sterritt, 166.

${ }^{33}$ Both quotes from Sterritt, 166.

${ }^{34}$ The first piece, from the beginning of the video up until minute 9.

${ }^{35} \mathrm{~A}$ riff is a short series of notes which are catchy, repeating, and rhythmic.
} 
musicians, usually coordinated through a leader. The emphasis is often on process over product, or perhaps, process as product. But, when a work is recorded, it can enter the popular culture as a work which is appreciated as an entity in and of itself, such as classics like Monk at the Five Spot, or Bill Evans at the Village Vanguard.

Gabriel Solis argues convincingly that jazz performances and recordings make it so that jazz has a kind of dual-life. Recently, he states, the emphasis on scholarship has focused on

The dialogic qualities of jazz, on the ways that performances are multiply authored, undermining the priority of the single author, and focusing on the emergent, processual aspects of jazz performance, rather than viewing jazz as simply a collection of texts. ${ }^{36}$

Perhaps the recent scholarship has swung too far away from the preceding postmodern conception of jazz works, which regards them as 'texts'the paradigm of completed, 'frozen' products.

Solis says

I would like to suggest that the protocols of action and imagination that people involved with jazz-musicians and audiences—use to engage jazz recordings allow for a coexistence of a dialogic-processual interpretation of jazz recordings alongside an understanding of them as products. ${ }^{37}$

Compare this to the earlier distinction between two kinds of entities: an entire world, as it is unfolding, versus the completed recording of a world. Extreme Static Classical Theists regard the world as only the recorded and completed artifact, whereas extreme Dynamic Open or Process theorists see it as only the unfolding (or 'becoming') itself. ${ }^{38}$

Those who embrace the improvisatory metaphor that I'm using can also say that the world has a dual-life, the present unfolding processual life and its static past history. And, just like how MOPDTK's note-for-note intrinsic duplicate of Kind of Blue is not of the same kind as the original, so God, if He created a complete intrinsic duplicate of a 'finished' world

${ }^{36}$ Solis, op cit., 333.

${ }^{37}$ Ibid.

${ }^{38}$ An Open Theist thankfully does not have to embrace a process metaphysics a la Hartshorne or Whitehead (but they may have to embrace some form of process). 
with libertarian free will or randomness, would not be duplicating the same kind of world as the original.

\subsubsection{Example 2: Improv Troupe Director-Participant-Christopher Guest's Model}

With improv performance there is usually no ruler, just rules. While an improv instructor during class gives directions and instruction, this is considered practice, not rehearsal.

There are many forms of improv, and I'll resign a short discussion to a footnote. ${ }^{39}$

In the metaphor envisioned, where 'the play' is all of history, I prefer to model it with Christopher Guest's method, with some significant variations.

Guest, after starring in Rob Reiner's This is Spinal Tap, a 'mockumentary' about a heavy metal band, went on to make many improvised mockumentaries himself. ${ }^{40}$ While Guest directed them, most were co-written with Eugene Levy. There wasn't exactly a script in the usual sense. The scripts were between 10 and 20 pages that merely outlined the scenes and story arc. They would also write up some brief background material for each major character. After casting was decided, filmmaking would consist in just throwing the actors together to start improvising the planned scenes. How each scene would develop was broadly settled, but how they would get there was up for grabs. No dialogue was written, being entirely improvised. ${ }^{41}$

\footnotetext{
${ }^{39}$ Improv plays are either short or long form. Short-form pieces are composed via the rules of improv games. Here's a simple one-'Questions.' The players get on stage, and ask for a setting suggestion from the audience (e.g., 'office,' 'beach'). Then they improvise, with the constraint that they can only ask questions. If someone fails, they are 'out,' until only one is left - the winner. Long form is much less constrained. Structures are provided to enable the players to create a play on the spot. One form, the La Ronde, works as follows. After an audience suggestion of a relationship, two of the players come out and start a scene. The other players form a line on the side of the stage. When it seems apt, the player next in line on the wall 'taps out' one of the players on stage, who exits to the back of the line, and a new scene begins. The next player will tap out the earlier of the two until everyone has had a turn, and it wraps up by a concluding scene with the first- and last-appeared characters. The goal is to develop the characters, their relationships, and to portray some alterations in the relationships.

${ }^{40}$ They include Waiting for Guffman, Best in Show, A Mighty Wind, and others.

${ }^{41}$ Usually they ended up with 30 hours of film, edited down to 1.5-2 hours for the final cut. Here's a trailer for Waiting for Guffman, just to give you a taste: https://tinyurl.com/
} 
Guest frequently uses the same actors across films. Frequent co-star Parker Posey herself compares what they do to jazz:

"It's like jazz," says Posey ... "Everyone is a different instrument and adds a different element. Guest is very much a maestro, an auteur... On Waiting for Guffman we'd do these long improvisations until the mag would run out. For like seven minutes, we're just lying on the floor, doing some acting exercise where everyone is talking and 'Yes-and-ing' each other." ... The director, she continues, "definitely created his own formula with actors that only worked in a specific kind of way. It had to do with the creating of a certain character or persona. And you don't know what you're going to say-you're just going to be in the moment with someone else ... and then something happens." 42

\section{The Divine Improv}

The Divine Improv is a live, one-shot performance, with no editing, no revision, and relatively minimal preparation. The Director has envisioned an improvised play with a broad story arc, but with unsettled fine details. Each player receives a description of their character, background, and relationships. But one thing the Director doesn't do is tell the actors exactly what the story arc is. If the story strays too far from his vision, he has several tools at his disposal. For starters, he can enter the play whenever he wishes as a character. ${ }^{43}$

There are also some arranged prop and audio conventions. The Director is free to just throw a prop on stage whenever he wishes, and the actors must work it into the narrative in as plausible and seamless a way as possible. For example, he could throw an engagement ring in a box on stage when two characters who are lovers are out to dinner. Or, another time, he could play audio of a car crashing, and so forth.

The actors may discern where the action is going and can try to thwart matters. But this Director is so smart, with enough tools, that she will get from them roughly what she wants in any case. One thing she wants is what is best for each character, within limits set by logic, the demands of justice, and respecting each character's autonomy.

y8v8x5nl. Musical numbers are usually not improvised.

${ }^{42}$ From https://tinyurl.com/yb8kczah

${ }^{43}$ Analogous to, for example, a voice on Mount Sinai, or, for Christians, as Jesus. Also angels or internal suggestions work as presence by proxy. 
These actors work on a "need-to-know basis." They do not know where they are going, for if they did, they would not arrive. Some of them may begin to discern the Director's benevolence for her characters, despite the play's vagaries indicating otherwise. The actors may begin to have faith in the end, glimpsing an ending which is surprising yet inevitable, but they cannot see how they will arrive. But a good improviser in this case will have trust in the Director's vision.

\subsection{SALUTARY UPSHOTS}

And now for some explanations how these metaphors elucidate or support dynamic views of God and His interaction with the world.

\section{Prayer can change things}

While improvisation is extremely flexible, the players are constrained by genre-specific considerations. A competent leader-participant will be responsive to changing facts 'on the ground' in order to meet the player's needs. The Classical Theist cannot accommodate this-any contribution God would have as leader would be exhausted once the play or performance begins. While His effects may be located during the present, this would only work if he foreknows everything which will happen-which is incompatible with OT. Blending an open future with the God of Classical Theism directing would be like Him delivering a video-recording of a conductor conducting a future performance-it would be unable to respond to changes.

According to Classical Theism, God responds affirmatively to prayer by actualizing a world where one's prayer for $\mathrm{x}$ is followed by $\mathrm{x}$. But on the Open view, if a prayer is free, it cannot be $100 \%$ predicted beforehand; therefore God must act in time in order to respond.

\section{The future is open}

Improvisation would be much more boring and low stakes if what will happen is fixed beforehand. Regardless of our epistemic shortcomings, if it is somehow metaphysically determined what will happen for any particular improv, then the practice would lose some of the features that make improv uniquely good-a product of random associationist thought tempered by improviser choice and skill. If we are engaged with God in a 
project of realizing a good, just, kind, and interesting world with highstakes difference-making choices, a model which is collaborative and open-ended seems more apt than a sole-composed static work entirely realized before time, where each player's lines are all written.

\section{Illustrating Providence: Freedom through constraint}

The 'providence' of the band leader or collaborative improv directorparticipant can be divided into the help before the performance and during the performance. ${ }^{44}$ First, the writing of the musical piece, or the development of the story arc, helps narrow the space of possibilities within which the artists can flourish in their given roles, and assigns them guiding structure. A good improv leader does not craft a piece for generic artists, but crafts and customizes the work in light of the particular artists involved. That there even is a song or play to perform depends on the improv leader, and if it is a good one, then it is thanks to her.

In jazz, in order for some individuals to perform their best, to exhibit their individuality in improvisation in the most excellent way, they may have to be not merely guided, but also goaded, by the band leader. A good leader often pushes their performers and, somewhat paradoxically, makes them freer by constraining them.

Solis notes that in some cases

the need to come to a session prepared to 'bring something' to a dialogue with other musicians - the ability to make 'musical conversation'-is clearly mediated by the authority (if not the authorship, per se) of the leader. ${ }^{45}$

He then describes a case where Charles Mingus, with his domineering personality, dominated his band members to get them

to bring every bit of themselves to the performance, so that the arrangements would be reflective of the individuals involved, rather than a mere collection of instruments. This goal is a composerly one. ... The performance culminated in a performance of "Meditations on Integration."

Buddy Collete describes a great moment during this performance:

\footnotetext{
${ }^{44}$ Henceforth, I will refer to both as 'improv leader,' and sometimes just 'leader.'

${ }^{45}$ Solis, 333.

${ }^{46}$ Ibid.
} 
Everyone was getting into it, playing solos. Mingus had two other trumpet players (besides Bobby Bryant) ... and he let them play. Bobby knew he wasn't going to get a chance. It was getting louder, more intense, really screaming. Then Mingus looked at Bobby and said, "Now!" Bobby at this point was so angry he hadn't played that he took his horn and blew the bell off it to show Mingus what he could do. And that did it. Mingus got the climax he wanted and the people just went crazy. ... He had psyched Bobby out. He knew Bobby was strong as a bull and he wanted a killer punch. ... There it was. Mingus had captured all these moods. He knew how to get them. He was like a little teaser: 'Not yet' or 'Maybe you won't get any' and then 'Okay, now!' It does work. It's what coaches do for fighters. Sometimes you need that little kick. ${ }^{47}$

I think what is analogous to aesthetic performance in the metaphor must be our moral performance or our will's alignment with God's. God is the jazz band leader or improvisational director of our moral behavior, according to this model, but many folk don't know they are playing, much less playing in an ensemble, and much less that there is a leader. That's why their songs stink and their solos detract from, rather than enhance, the communally produced piece. The way we are directed does not make us unfree-it makes us more free to be able to realize the flourishing we are intended for.

\section{God's risks, assurances, and sovereignty}

Most believers I know accept, and should accept, both of the following:

a. God is looking after my welfare.

b. Terrible things will happen to me.

While we think that God may test us and allow us to suffer, we believe that (a.) still holds despite our calamities, since we think that ultimately He will not abandon us. ${ }^{48}$

Given that the improv leader employs fallible humans, there is no guarantee that the composition will be as good as it can be. Given the freedom artists in the medium enjoy, and a fickle world, there is no guarantee that, for example, one's solo will shine by being free from a distracting

${ }^{47}$ Collette 2000, 34-35. My source is Solis ibid., 334.

${ }^{48}$ C.f., for example, Habbakuk 3:16-19. 
colleague, or that one's presuppositions laid out in the improv will be noticed, remembered, and so forth. But you can nevertheless trust the leader since, if there is a track record, one has seen how the leader has often pulled the play/song back from the brink, such as by helping a character's suffering make sense or tying together loose ends.

Many complain that views such as OT entail that God is not sovereign and is undermined by no longer being the sole author of the world. The correct response to this is nuanced.

How many authors are there for a jazz performance or improvised play? A case can be made for one, and a case for many. ${ }^{49}$

I think we can have it both ways. Solis mentions how, even though a jazz piece may be realized by a group collaborating and soloing, there can still be "reasonable individual authorial attributions" (Solis, 331). For example, the first recording of Monk's "Evidence" features Milt Jackson on vibraphone. While other, later versions did not, they were nevertheless versions of the same piece. But if, on the first recorded version, the vibraphonist improvises-why is he not an author of the piece as well? Especially if it is true, as mentioned, that the composer/performer distinction breaks down?

The answer for why he is not an author is that the differences he brings do not make a difference to it being the piece that it is, while they essentially bring to it something that makes it the version that it is. (The initial album was to showcase Jackson's work). ${ }^{50}$

With jazz, the non-authorial improvising performers are what we could call 'essential version-realizers.' While their solos do not make the song be the one that it is, they do make it be the version it is, distinct from any other performance of it. Improvising band members, while less than coauthors, are more than merely instruments to instantiate the composer's vision.

So, if we are the musicians in God's band, playing His piece, we also are less than co-authors but more than instantiating instruments. While the 'head' or coarse-grained structure of the piece is settled, we determine the fine-grained details and hence complete the work. We, like the band members, make a contribution to it being the piece it is.

Things are the same, mutatis mutandis, with improv. Maybe all the world is God's stage, but we are not merely players. The structure is

${ }^{49}$ When there's a single composer.

${ }^{50}$ Milt Jackson and The Thelonious Monk Quintet (Blue Note BLP-1509, 12", 1956). 
broadly determined, but we decide how some of the particulars go. We are more than mere actors given a script, yet less than co-authors. Below an author is a contributor. We contribute to the play, and if it weren't for us, the play would be different - but not a different play. We may 'author' our lines totally, but this is not enough to make us a co-author. Maybe we cannot choose our role, but can choose how we play it.

The point is that these analogies retain God's sovereignty, while allowing us to make a difference-making contribution to the world. And nothing about this view denies that God could take over to any degree $\mathrm{He}$ wished, if He so wished. I don't know how often He does, but we can see many things go on that are decidedly not what He wishes.

\section{How randomness fits in the picture}

Randomness, non-determinateness, or chance plays a crucial role in improv. If improv is, as Pietropaolo says, a "stochastic composition process," then how does the stochastic part come in?

I don't think the analogies provide much illumination into what randomness $i$, but I do think they can illustrate how randomness is employed, both by us and by God. In improv, unexpected things (e.g., notes, chords, puns, actions) just 'come to us,' and to our colleagues, and from the audience, and we need to work with that. Concentrate on attempting to make a great plan pan out, come what may, or on preparing for any possibilityand the whole thing falls apart. But, one can practice a lot beforehand so that more and better things come to one more easily, and actions undertaken more skillfully. We can ask the leader to help hone our skills. Analogously, we will be put into situations where our morality and character will be tested. At some point deliberation must end and action begin, and how we weigh and measure will be a somewhat intuitive and characterbased matter. 'Growing' as a performer is analogous to forming one's moral character. (These metaphors lend themselves somewhat to a 'soulmaking' theodicy like that proposed by John Hick. ${ }^{51}$ )

Another point about randomness-'stuff' happens, and it often seems to have no rhyme or reason. A bad split-second decision, or a slow reaction time, which could be caused by lack of sleep (which may depend on the vagaries of that damn alley-cat's estrous cycle), can make the difference between life and death. History is full of stories of battle where who lived

\footnotetext{
${ }^{51}$ Such as in Hick 1981.
} 
and died had nothing to do with a soldier's skill, character, cleverness, or lovableness. There are many close calls, when we are happy that God is looking after us. Yet, sometimes other fine people aren't so lucky, and we'd be terrible if we used that as evidence that God doesn't care for them. We have to be careful with explanations of purpose and trying to explain away all randomness as actually pregnant with purpose. It could be that there is no reason some events occur, ${ }^{52}$ and a good improviser will often be hampered by seeking explanations when things go badly.

In a striking passage from Stephen King's The Stand (not all of which I agree with, in characterization or tone) a narrator states:

The beauty of religious mania is that it has the power to explain everything. Once God ... is accepted as the first cause of everything which happens in the mortal world, nothing is left to chance ... or change. Once such incantatory phrases as "we see now through a glass darkly" and "mysterious are the ways He chooses His wonders to perform" are mastered, logic can be happily tossed out the window. Religious mania is one of the few infallible ways of responding to the world's vagaries, because it totally eliminates pure accident. To the true religious maniac, it's all on purpose. ${ }^{53}$

Is the reason you didn't get the job over your less-qualified competitor because God is punishing you for not paying enough attention to your children? Or because of racism, sexism, or ableism? Or is it because in the interview you came off as arrogant? Or is it to save you from a commute where God was certain you would die? Or is it because a member of the committee forgot to set their alarm at that conference long ago, and in so doing and waking up late, happened to meet one of the future candidates in a cafe line and liked the cut of their jib? Likely you'll never know. In any case, however, the answer of what to do is somewhat like the improviser's-we've got to roll with it.

This does not mean that you should not be perturbed by anything, nor seek to rectify injustice. Rather, that you should foster a resilient and flexible disposition as much as you can-you're going to need it.

\footnotetext{
${ }^{52}$ Or that chance is the reason.

${ }^{53}$ Book II chapter 48 .
} 


\subsection{CONCLUSION}

If God constructs the world like how one directs an improvised playthen what is the genre? Genres not only shape the plot and themes, they shape expectations. If it's a comedy, expect some laughs. If it's a mystery, expect a crime and expect some false leads. While many good works are genre-bending, usually genre-crossing leads to disaster, like if aliens landed halfway through the film Chinatown, or if a wizard was the main explanation behind the aliens in Alien.

In improv, as in daily life, we may be terrified that we won't know what to do. But if we have a good Director, or Muse, we should not worry. Stephen Pressfield relates the following:

Patricia Ryan Madson taught improv at Stanford for years. ... Patricia has an exercise that she calls "What's in the Box?" She asks her students to imagine a small white box. Imagine a lid on this box. Now lift the lid. What do you find inside? Sometimes students say a diamond. ... Sometimes a pomegranate. The trick is, there is always something inside the box. ... Patricia was addressing her students' seminal terror: that they would get up on stage and draw a blank. The professional trusts the mystery. He knows that the Muse always delivers. She may surprise us. She may give us something we never expected. But she will always put something inside the box. ${ }^{54}$

Alasdair MacIntyre also has written about genre, and, in After Virtue, he compares us to authors, but of our own lives, and stresses the importance of narrative:

thus the narratives which we live out have both an unpredictable and partially teleological character. If the narrative of our individual and social lives is to continue intelligibly ... it is always both the case that there are constraints on how the story can continue and that within those constraints there are indefinitely many ways that it can continue. ... I can only answer the question 'What am I to do?' If I can answer the prior question, 'Of what story or stories do I find myself a part? ${ }^{55}$

It will help the players' performance to discover what genre of play they are in. If they are acting like they are in a comedy, when in fact they are in a tragedy, aesthetic disaster will ensue. But it may well be that having to

\footnotetext{
${ }^{54}$ Pressfield, Turning Pro 117.

${ }^{55}$ MacIntyre 1981, 216.
} 
discover themselves what genre they are in is instrumental toward it being the instance of the genre that it is.

We do not get to fully determine what genre we are in. Part of the scoundrel's problem is that he believes he is in a heroic tale, where in fact he is in a tragedy, with himself as the anti-hero. A buffoonish blowhard may believe he is a stable genius and part of the greatest riches-to-greaterriches success story, whereas he is actually in a tragi-comedy about a spoiled rich boy and the soul-destroying effects of greed, power, and narcissism.

Maybe if we came to realize that we are all primarily in a love story, or collectively playing a love song, and are not composing, much less directing, on our own, we would come to change our expectations, attitudes, and show some real chops.

The world which is a love-themed improvised artwork is unique. This is the only love story wherein the very characters of the story can come to realize that they are both the story's subjects, and the story's collaborators, and that the story is also about a perfect loving author, who wants to play with them-not as playthings, but as playmates. Hence the story of the world reaches outside of itself.

The love which the work is about is not only represented by the work, the work is constituted and sustained by the very love which it is about.

\section{BIBLIOGRAPHY}

Bresnahan, Aili. 2015. Improvisation in the Arts. Philosophy Compass 10 (9): 573-582.

Broad, C.D. 1923. Scientific Thought. New York: Harcourt and Brace.

Clark, Kelly James. 2014. Religion and the Sciences of Origins. New York: Palgrave Macmillan.

Collette, Buddy (with Steven Isoardi). 2000. Jazz Generations: A Life in American Music and Society. London/New York: Continuum.

Divers, John. 2002. Possible Worlds. London: Routledge.

Frigg, Roman. 2010. Models and Fiction. Synthese 172 (2): 251-268.

Gendler-Szabo, Tamar. 2000a. The Puzzle of Imaginative Resistance. Journal of Philosophy 91: 55-81.

-2000b. Thought Experiment: On the Powers and Limits of Imaginary Cases. New York: Routledge.

Haack, Susan. 1993. Evidence and Inquiry. Malden: Wiley-Blackwell. 
Hefter, Hertzl. 2013. In God's Hands; the Religious Phenomenology of R. Moredechai Yosef of Izbica. Tradition: A Journal of Orthodox Jewish Thought 46: 43-65.

Heller, Mark. 1990. The Ontology of Physical Objects: Four-Dimensional Hunks of Matter. Cambridge: Cambridge University Press.

Hick, John. 1981. "An Irenaean Theodicy" and "Response to Critiques". In Encountering Evil: Live Options in Theodicy, ed. Stephen T. Davis, lst ed., 39-52, 63-68. Edinburgh: T \& T Clark.

King, Stephen. 2008. The Stand. Anchor Books.

Lanser, Susan. 1981. The Narrative Act. Princeton: Princeton University Press.

Lebens, Sam. 2015. God and His Imaginary Friends: A Hassidic Metaphysics. Religious Studies 51: 183-204.

- 2017. Hassidic Idealism: Kurt Vonnegut and the Creator of the Universe. In Idealism: New Essays in Metaphysics, ed. T. Goldschmidt and K. Pearce, 158-177. Oxford: Oxford University Press.

Leiner, Mordechei Yosef. 1995. Mei HaShiloah. (Bnei Brak, in Hebrew).

Lewis, David. 2001. On the Plurality of Worlds. Revised ed. Wiley-Blackwell. London, England.

Lewis, C.S. 2012. Mere Christianity. London, England: William Collins.

MacIntyre, Alasdair. 1981. After Virtue. University of Notre Dame Press. London, England: Gerald Duckworth.

McCall, Storrs. 1994. A Model of the Universe. Oxford: Clarendon.

Monson, Ingrid. 1995. The Problem with White Hipness: Race, Gender, and Cultural Conceptions in Jazz Historical Discourse. Journal of the American Musicological Society 48 (3): 396-422.

Olson, Barbara. 2006. 'Who Thinks This Book?' or Why the Author/God Analogy Merits Our Continued Attention. Narrative 14 (3): 339-346.

Owens, Thomas. 1994. Bebop: The Music and Its Players. New York: Oxford University Press.

Pietropaolo, Domenico. 1989. Improvisation as a Stochastic Composition Process. In The Science of Buffoonery: Theory and History of the Commedia Dell'arte, ed. D. Pietropaolo, 167-175. Ottawa: Dovehouse.

Polkinghorne, John. 1989. Science and Providence: God's Interaction with the World. Templeton Press.

Pressfield, Stephen. 2012. Turning Pro. Black Irish Entertainment.

Sanders, John. 2007. The God Who Risks: A Theology of Divine Providence. Downers Grove: IVP Academic.

Sider, Theodore. 2002. Four-Dimensionalism. Oxford University Press. Oxford, England: Clarendon Press.

Solis, Gabriel. 2004. 'A Unique Chunk of Jazz Reality': Authorship, Musical Work Concepts, and Thelonious Monk's Live Recordings from the Five Spot, 1958. Ethnomusicology 48 (3): 315-347. 
Sterritt, David. 2000. Revision, Prevision, and the Aura of Improvisatory Art. The Journal of Aesthetics and Art Criticism 58: 2.

Szabo-Gendler, Zoltan. 2008. Things in Progress. Nôis 42 (1): 499-525.

Wooldridge, Darryl. 2014. Proleptic Spiritual Transformation: Living in the Not Yet (Doctoral Thesis, North-West U., Greenwich School of Theology).

Zaunbrecher, Nicolas. 2011. The Elements of Improvisation: Structural Tools for Spontaneous Theatre. Theatre Topics 21 (1): 49-60.

Open Access This chapter is licensed under the terms of the Creative Commons Attribution 4.0 International License (http://creativecommons.org/licenses/ by $/ 4.0 /$ ), which permits use, sharing, adaptation, distribution and reproduction in any medium or format, as long as you give appropriate credit to the original author(s) and the source, provide a link to the Creative Commons licence and indicate if changes were made.

The images or other third party material in this chapter are included in the chapter's Creative Commons licence, unless indicated otherwise in a credit line to the material. If material is not included in the chapter's Creative Commons licence and your intended use is not permitted by statutory regulation or exceeds the permitted use, you will need to obtain permission directly from the copyright holder.

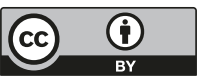

